\title{
Creative Writing in Europe and the United States and Chinese Writing Teaching Reform
}

\author{
Wei Li \\ College of Humanities and Fine Arts \\ Xi'an International University \\ Xi'an, China
}

\begin{abstract}
The purpose of this study was to achieve the reform of Chinese writing teaching by referring to creative writing teaching in Europe and the U.S. Here we analyze the characteristics of creative writing teaching in Europe and the U.S., problems existed in current Chinese writing teaching, and the illumination from creative writing teaching in Europe and the U.S. to Chinese writing teaching. We mainly focus on core aspects such as teaching idea, teaching method, practice and teacher sources. The results we obtained demonstrate that the creative writing in Europe and the U.S. would help with difficulties that the current Chinese writing teaching reform faces, and can be used as a reference to Chinese writing teaching reform.
\end{abstract}

Keywords_creative writing; Chinese writing; teaching reform; illumination

\section{INTRODUCTION}

There are two meanings for creative writing. The first is its literal meaning: writing in a creative way, with the text as form and works as carrier; secondly, it means the creative grammatology, which studies the creative writing rules and the laws of creative writing teaching from teaching aspect. According to different functions, the creative writing can be divided into three categories. The first category is the writing of reading text for enjoyment, including novel, poem, essay, script, etc. The second category is the writing of creative text for production, including various proposals and plans, such as advertising proposal, event plan, etc. The third category is the writing of functional text for reference, including official document writing, news writing, economic document writing, etc. [1]

The creative writing teaching in European and American universities can be traced back to nearly one hundred years ago. The University of Lowa in the U.S. originally started the courses of creative writing at the end of the 1920s. With the establishment of creative writing discipline in American universities, it is quickly spread to Europe, Australia and Asia. At present, in western developed countries, the creative writing has become a mature discipline including 20 sub-categories and three education levels from undergraduate, postgraduate to doctor. In China, nevertheless, the creative writing discipline is still at its primary stage. The university firstly introduced the creative writing discipline is Hong Kong Baptist University. It established the major of creative writing in 1984, and founded the "College of Humanities and Creative Writing" in 2012. As to mainland China, the Creative Center Shanghai University is the first institution devoted into the study of creative writing theory and teaching. It started the creative writing class for graduates from 2010 and started to recruit undergraduates from 2011. In addition, Fudan University and Beijing University started to recruit creative writing undergraduates from 2010 and 2013 respectively. Now, several universities in Shanghai, Beijing, Wuhan, Guangzhou, Xi'an, Chongqing, Hangzhou, etc have carried out creative writing teaching. However, compared to creative writing teaching in Europe and the U.S., the creative writing teaching in China just starts. The theory, training system and curriculum system have not been formed, and the discipline construction is still at exploratory stage. Based on the content mentioned above, it is imperative to conduct the reform of Chinese writing teaching by referring to the creative writing in Europe and the U.S.

\section{CHARACTERISTICS OF CREATIVE WRITING TEACHING IN EUROPE AND THE U.S.}

Nowadays, no country in the world can compete with the U.S. at the mention of cultural industry. The prosperity of the U.S. not only depends on its military capability and technology, but also it is inseparable from its strong cultural industry. Shown as relevant data, in the U.S., the cultural industry is the primary industry, as well as the largest export industry. The cultural industry occupies more than $20 \%$ of the total Gross Domestic Product of the U.S. [2]. It also can be seen that the cultural industries in European countries are developed. So, why the cultural industries both in Europe and the U.S. are developed? As many writers, creative talents in Europe and the U.S. are cultivated through creative writing discipline, this is closely related to the creative writing discipline. Therefore, in order to achieve effective reform of Chinese writing teaching, it is significant to study the characteristics of creative writing teaching in Europe and the U.S. Such characteristics mainly include the following six items:

\section{A. The teaching idea is suitable for modern development}

In China, it is traditionally believed that writing is mysterious and personal. Only people endowed with writing can become writers. Thus, writing cannot be taught, and writers cannot be cultivated through writing teaching. However, the concept of creative writing believes that writing can be taught and creative idea can be aroused through teaching; that is to say, writers and people involving in cultural industry can be cultivated through teaching.

As we can see, in the phrase "creative writing”, "creative" comes first and followed by "writing”. Such an order implies 
what is more important. From the view of creative writing teaching, creativity is much more important than writing skills. As we all know, creative ideas nourish the writers. Therefore, the creative writing teaching should not only teach the students how to write, but also should teach them how to stimulate creative ideas. [3]

Benefited from such an advance teaching idea, many excellent writers and talents are cultivated for cultural industry. It is enough to demonstrate that the teaching idea proposed according to creative writing in Europe and the U.S. suits the demand of current social development.

\section{B. The teachers are double-position type}

In the U.S., there mainly are two kinds of methods for the teaching of creative writing: process teaching and workshop type teaching. Generally, the workshop type teaching is mainly leaded by people who are teachers and writers at the same time. We call such people as double-position type teachers. As to process teaching, it emphasizes on collective cooperation, involving collective creation, collective writing, and collective revision. Therefore, only writers with teaching qualification are qualified for teaching creative writing.

The teachers teaching creative writing are from different professional or industry backgrounds, including writing, literature, linguistics, history, sociology, cultural study, etc. However, all teachers from different backgrounds have writing experience, and most of them are writers in different fields. They, with their individualized methods, styles and cultural accumulations, bring different personal resources into the classroom. The instruction of those creative writing teachers ensures a high quality teaching, makes the writing theory and practice highly compatible, enables the teaching focusing on students' creative writing practice, and cultivates many outstanding talents for cultural industry in the U.S.

\section{The teaching is centered on students' creative writing practice}

The creative writing in Europe and the U.S. attaches great importance to the practicality of teaching, and the training is centered on the students' creative writing. The book Teaching Creative Writing Practical Approaches is a powerful evidence. This book contains 50 examples of creative writing teaching from all over the world, providing readers with various detailed creative writing teaching methods and training processes. Among those methods, the workshop type teaching is widely applied. In a sense, the workshop type teaching is the soul of creative writing teaching. It not only breaks the convention of traditional literature teaching, but also integrates the writing theory into practice through the form of writing guide. Those methods are experimental, but they are finally implemented on students' writing practice. The high consistency between writing theory and practice is ensured. [4]

\section{Group interaction is paid attention to during the whole teaching process}

During the whole teaching process of creative writing, group interaction is paid attention to. In book Teaching Creative Writing Practical Approaches, 50 examples of creative writing teaching are contained, and all of them are achieved through group interaction. From the perspective of teaching subject and object, group interaction is characterized by teacher-student interaction and student-student interaction; from the perspective of teaching unit, group interaction is characterized by group-group interaction. The teacher plays a role configurating and scheduling the group interactions, and the students can realize self-expression and self-motivation in mutual communication and constant interaction.

\section{E. The teaching focuses on cultivating students' creative thinking}

There are two new views in creative writing: one is "creativity first, writing second", and the other is "see writing through the vision of cultural and creative industries" [5]. Creative thinking comes from creativity; therefore, creative writing means writing in a creative way. That is to say, the nature of creative writing is writing in a creative way. The cultivation of students' creativity is the key point to teaching of creative writing. To cultivate students' creativity, the cultivation of the creative thinking should be put at the first place. Creative thinking runs through whole creative activity, and it is the base for creative activity. Therefore, in order to cultivate students' creative thinking, the teachers should design and develop teaching creativity to form the independence, linkage, diversity, leapfrogging and comprehensiveness of students' thinking [6].

\section{F. Great importance is attached to the design and development of teaching creativity}

In book Teaching Creative Writing Practical Approaches, the teacher's unique creativity in teaching is reflected in various teaching methods. The design and development of such teaching creativity is obtained from actual teaching experience. Why great importance should be attached to the design and development of teaching creativity? A uniform teaching method cannot cultivate students' creative thinking because the formation of creative thinking is closely related to the brain thinking system. Firstly, the brain thinking system is open, which requires us to constantly observe the object of study to acquire new information comprehensively, and to continuously learn and practice. Secondly, the brain thinking system must break existing knowledge structure and cognitive pattern, which requires us to think differently and to pursue change. Therefore, designing and developing different teaching methods to meet the goal of cultivating students' creative thinking is the work of a teacher and a prerequisite to guarantee the teaching quality.

\section{Problems Existed in Chinese Writing Teaching}

Since the reform and opening-up in 1978, the grammatology theory and the theory of writing teaching have been constantly updated, and fruitful results have been achieved. Although the writing teaching has been moved forward through various reforms and certain results have been achieved, the effectiveness of writing teaching is still unsatisfactory, even has been questioned. On the one hand, though students' theoretical literacy of writing has been improved after completing writing courses, they have grandiose aims but puny abilities. Most of them lack confidence and interest in writing. On the other hand, from the perspective of social demand, Chinese writing talents trained 
cannot meet the social demand of cultural industry. The cause of such situation is related to the following problems existed in writing courses.

Firstly, the teaching content fails to meet the development demand of cultural and creative industries. The development of cultural and creative industries has been clearly contained in Culture Development Program during the National 11th Five-Year Plan Period. The "powerful cultural country" has been proposed during the 18th National Congress of Chinese Communist Party, and the "cultural confidence" has been proposed during the 19th National Congress of Chinese Communist Party. All these ideas have strengthened and boosted the development of China's cultural and creative industries. However, the development of China's cultural and creative industries is lagging behind because the lack of creative talents, especially creative writing talents. Though there are Chinese writing courses, the literature writing and official writing are focused on instead of the cultivation of core employees for cultural and creative industries. Therefore, the content itself fails to meet the demand of creative writing talents by cultural and creative industries.

Secondly, customarly Chinese writing teachers preferred to focus on theory, although a reform on Chinese writing teaching has been carried out for 30 or 40 years, there hasn't been any significant breakthrough on the teaching method and the theory is still the main content, Thus, the effectiveness of writing training is not ideal, and the training goal cannot be achieved successfully. Besides, in classroom teaching, teachers feel delighted in imparting knowledge, such as the definitions, classifications, characteristics, functions and essentials of different literary forms, but lack effective practical activities. Even though teachers have realized the importance of practical training and have increased the amount of training. Teaching students to learn write through writing practice is a good idea. Unfortunately, there is no big breakthrough in teaching methods.

Thirdly, Chinese writing courses are not valued by student. It is found that even the students from the Department of Chinese Language and Literature do not value the writing courses, and their enthusiasm of learning is not very high. Most of the students don't want to be writers or devote into creative writing in the cultural and creative industries after graduation. They do not think that the level of writing has any relationship with their future development. In addition, the teaching methods are relatively simple, lacking creativity, and the ways to motivate students' learning enthusiasm are not enough.

In addition, the number of qualified teachers is insufficient. Most of the teachers teaching writing courses are graduated from non-writing majors. Some writing teachers even lack writing practice. Naturally, without adequate teachers it is difficult to improve the teaching quality.

\section{ENLIGHTENMENT FROM CREATIVE WRITING IN EUROPE AND THE U.S. TO CHINESE WRITING TEACHING REFORM}

The result of talent training in Europe and the U.S. for nearly a hundred years has demonstrated that creative writing teaching is effective. The characteristics of creative writing teaching are precisely the weak points of Chinese writing teaching. Therefore, taking creative writing teaching in Europe and the U.S. as a reference, difficulties in Chinese writing teaching can be overcomed and breakthrough can be made. The core elements of the creative writing teaching in Europe and the U.S., such as teaching idea, teaching method, practical trainning and teacher sources can be referred for Chinese writing teaching.

\section{A. Teaching Idea}

Firstly, the creativity and writing are linked together. It thinks that creative writing means writing in a creative way, which highlights the essential characteristics of creative writing. It makes us realize that writing teaching should cultivate the students' creativity, which is different from the traditional Chinese writing teaching. Traditional Chinese writing only pays attention to the improvement of the students' writing skills. In fact, creative activities go through whole writing process from conception to finished works. If it fails to train the students to think in a creative way, it is difficult to broaden their scope of mind and stimulate their creativity; thus, it is difficult for students to write works with relatively high quality.

Secondly, the mystery of writing is unveiled. It believes that writing can be taught and writers can be cultivated through teaching. The "writers" here is different from the "professional writers" in a narrow sense. It is more extensive, including both "professional writers" and all those with creative ability in writing. If you can write, you can be called a "writer." [7] Therefore, the writing courses should take on the task of cultivating writers to really connects the literary creation and cultural and creative industries. Since it is badly in need of writers and cultural-creative talents, it is extremely important that the writing teaching should serve the cultivation of writers and cultural-creative talents.

\section{B. Teaching Method}

There mainly are two kinds of methods for the teaching of creative writing: process teaching and workshop type teaching. The process teaching is suitable for large class teaching, from conception, creation, first draft writing to revision and finalization. The interaction, including discussion and thinking collision, goes through the whole teaching process. The teaching content involved in this form of teaching is different from that in traditional Chinese writing teaching. The traditional Chinese writing teaching attaches great importance to the structures and writing skills, while ignores the process of conception and creation. However, conception and creation are significant for writing. The ideas of "creative idea can be learned" and "writing can be taught" can be reflected in and achieved through process teaching. The teaching process is conducive to the students' understanding of the whole process of writing, the development of the students' creative thinking, and the improvement of students' writing level and interest. The significant characteristic of workshop type teaching is small-class teaching. Most of teachers for workshop type teaching are writers. The teaching content is centered on students' creative writing practice. The workshop type teaching is achieved through various activities, discussions and lectures. More attention is paid to the group interaction, and teachers will design and develop different teaching ideas according to 
different teaching objectives and content in order to guide students' reading and writing practice. Through such teaching method, every student is given the chance to present their own works, while the others are entitled the rights to propose revision suggestions. As a window for the breakthrough of Chinese writing teaching, the process teaching and workshop type teaching aiming at the shortcoming of Chinese writing can be referred to.Therefore, is worth to study and discuss how to localize the workshop type teaching and use it to improve the Chinese writing teaching.

\section{Practical Training}

The outstanding characteristic of creative writing teaching is practicality, which is centered on the students' creative writing training through various methods. Such teaching is entirely depended on the teaching creativity of the teachers. Such practical teaching is worthy of reference. Firstly, in order to meet actual needs of students, the teachers should develop and design practical teaching ideas according to different teaching objects, other than using stereotyped and stylized teaching methods. Secondly, the teaching principles of the practice courses should be followed, including a) the cooperation principle: namely teacher-student discussion at an equal position; b) the encouragement principle: namely encourage students more; c) the non-contest principle: make a record other than contradict when receiving criticism; d) the constructive principle: propose more constructive suggestions other than blindly follow. Thirdly, the interaction type lecturing should be achieved during practical teaching, mainly including questioning, discussion, group activity, exploration, collective creation, group research, etc. Finally, it should make classroom teaching a good experience. But how to let students experience creative writing through teaching? This requires the teachers to present their experience of the creation process to the students. Therefore, develop and design practical teaching ideas is a must-do for every responsible writing teacher.

\section{Teacher Sources}

At present, in Europe and the U.S., most teachers teaching creative writing are masters or doctors graduated from the major of creative writing. All these teachers can write in relatively high quality. They are writers with their own works and able to understand the teaching rules at the same time; therefore, they are all double-position type teachers. The double-position type teachers guarantee the high teaching quality. However, most of the Chinese writing teachers are graduated from non-writing majors. Therefore, great attention should be paid to the selection of teachers. Professional writing teacher with relatively high writing level should be the standard for writing teacher selection in future.

\section{CONCLUSION}

As creative writing in Europe and the U.S. is advance in teaching idea and rich in practice, it can be used as a reference to for a Chinese writing teaching reform. However, it is only the first step. Upon the research and practice of creative writing teaching, creative writing teaching with unique charm will replace traditional writing teaching in more and more universities. Also, the construction of creative writing discipline will gradually become mature. At present, the construction of creative writing discipline in colleges and universities in China is at the exploratory stage, which provides a lot of space for us to further study creative writing.

\section{REFERENCES}

[1] H. Ge and D. Xu, "An Outline of Creative Writing Discipline Construction in China," [J]. Exploration and Free Views, p.6, 2011.

[2] M, McGell, "The Program Era: Postwar Fiction and the Rise of Creative Writing (preface),” [M]. Guilin: Guangxi Normal University Press, p. 1, 2012. (In Chinese)

[3] D. Xu and H. Ge. "Core Idea, Theoretical Basis and Teaching Method of Subject Education," [J]. Writing, p.3, 2016.

[4] W. Elaine, Y. Lv and Y. Song (Trans.). "Teaching Creative Writing Practical Approaches.” [M]. Beijing: China Renmin University Press, 2014. (In Chinese)

[5] H. Ge. "Discipline Orientation of Creative Writing," [J]. Journal of Xiangtan University (Philosophy and Social Sciences), p. 9, 2011.

[6] Z. Zhao, "Creative Writing: Application of Creative Thinking in Writing Teaching.” [J]. Writing, P. 1, 2015.

[7] H. Ge and D. Xu, College Creative Writing-Literature Writing, [M]. Beijing: China Renmin University Press, 2017. (In Chinese) 